\title{
The Queen on the big screen(s): outdoor screens and public congregations
}

\author{
Ruth Adams
}

Since the Queen's Golden Jubilee in 2002, big screens in public places relaying live broadcasts to large crowds, often very near to the 'real' action, have become an increasingly important and visible element of royal celebrations. It might be expected that in our current era of media fidelity, diversity and ubiquity, these mass congregations would lose their appeal but the opposite would seem to be the case. An estimated 1 million people watched the Golden Jubilee 'Party at the Palace' concert on screens in the Mall, 90,000 watched the royal wedding in Hyde Park and Trafalgar Square in 2011 and many of the million people who lined the River Thames for the 2012 Diamond Jubilee pageant watched the event on the fifty screens along the route, with a further 90,000 watching in Battersea Park.

This arguably represents a reversal of the dominant trend during the second half of the twentieth century, when the primary means by which public events were transmitted and received was by television in domestic contexts, leading to anxieties that public culture and public life had been displaced by a more atomised, private mode of engagement. However, as Scott McQuire observes, 'the explanatory value of such a narrative is declining', and 'the current expansion of media screens from predominantly fixed and private locations to mobile and public sites has introduced a new set of questions. ${ }^{1}$ How, for example, should we understand this new type of public occasion, the transmissions which are their focus and their 'not-quite-liveness'? ? $^{2}$ What motivates people to travel and congregate to view events on proximate screens rather than watching at home? Are such events a means of compensating for a fragmentation of community and audience in a postmodern age of media proliferation? Do they represent the reinvention of public space? Barker suggests that 'We might say that a new notion 


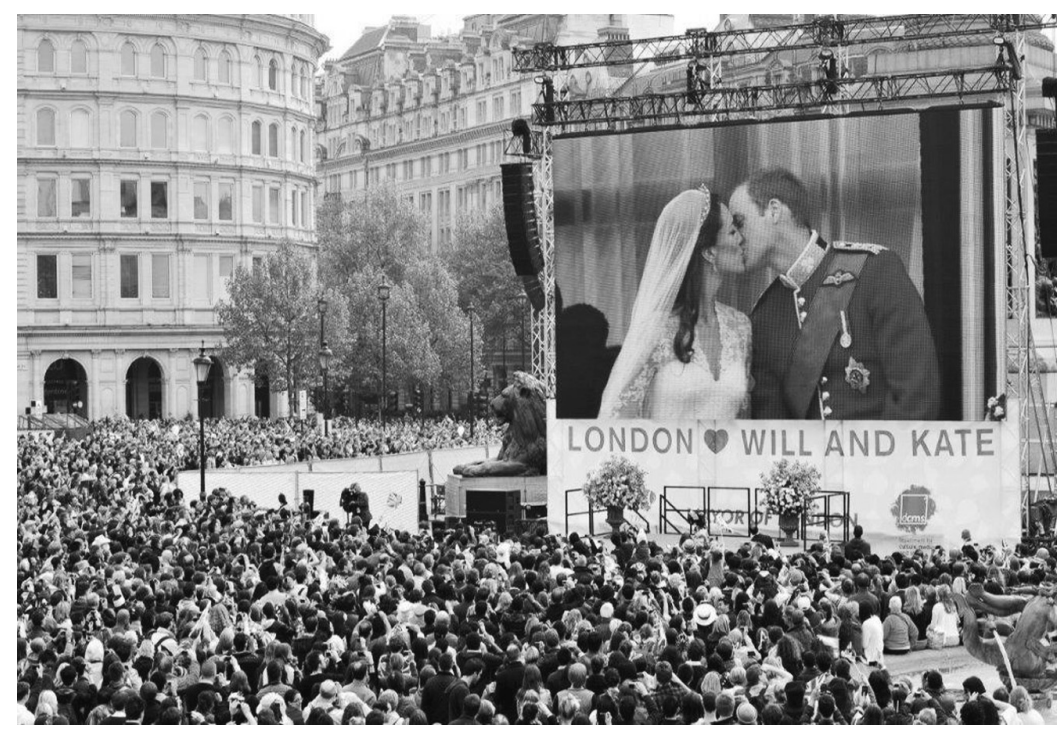

25 Spectators in London's Trafalgar Square view the royal couple's post-nuptial kiss on the big screen, 2011 (AP Archive).

is emerging from this, which we could call eventness: that is, the creation of and participation in senses of heightened cultural togetherness. ${ }^{3}$ Does the content determine the nature of these phenomena? Are public broadcasts of royal celebrations qualitatively different from, for example, sporting, theatrical or political events transmitted in a similar fashion? This chapter seeks to answer some of these questions in relation to live public screenings of royal ceremonial and celebration. The novelty and popularity of these screenings make them, I would argue, a legitimate area of research, and one that has not yet been explored in relation to royal events, although work has been done on live broadcasts in sporting, theatrical and other cultural environments. This omission might be understood in the context of a more widespread neglect of topics relating to the British monarchy by academia, an inattention that is perhaps 'perplexing', ${ }^{4}$ given its prominence in British culture and society, and the strong emotional attachment demonstrated by a significant proportion of the population. Tom Nairn argues that it is a mistake for scholarly analysis to dismiss popular interest in the royals as 'mass idiocy', 5 and that it should instead be recognised as a significant element of the UK's rather complex and paradoxical national identity.

In this chapter I examine British royalty's relationship with the media, particularly since the advent of television, and review existing research on media 
technology, on the concept of 'liveness' and the uses of public screenings in a variety of contexts. In doing so I try to identify some conceptual frameworks that illuminate these more recent developments. I also introduce some findings from a small empirical research project, which canvassed the experiences of people who watched royal events on big screens in London in 2011 and 2012, namely the wedding of Prince William and Kate Middleton, and the celebrations for the Queen's Diamond Jubilee. This research is far from comprehensive or conclusive, but it does, I believe, flag up some key themes and issues, and gestures towards possibilities for future research.

Ten respondents completed long-form open-ended questionnaires, and in four cases this was followed up by semi-structured face-to-face interviews lasting between thirty minutes and one hour. The respondents were recruited through a variety of means, including personal recommendation, social media and university research calls. Among this group the Jubilee river pageant on 3 June 2012 was the most popular event, with eight of the ten attending. Four had attended the screenings of the Jubilee concert the following day, but only one had watched the final day of the weekend celebrations, the more traditional Thanksgiving Service at St Paul's Cathedral and procession to Buckingham Palace. Six of the respondents had also watched the wedding of Prince William and Kate Middleton on public screens in April 2011.

Only one respondent identified as male, and all but two were under thirty. Most were educated to degree level, and a number had or were studying for postgraduate qualifications. Four were not native to the UK, but all were living in the UK when they attended the events in question. The relatively international nature of the group reflects the demographic of the student body of my university, but is also indicative of the British royal family's global appeal. Several respondents commented on the relatively high proportion of foreigners they perceived at the events they had attended. Although this would appear to challenge Tom Nairn's assessment that '[v]isitors and outsiders may not understand this "irrational" identification, because they do not share the community inwardness it represents', ${ }^{6}$ a number of my respondents from overseas stated that their motivation for attending was at least partly 'anthropological', that they wanted to 'see how British people experience this kind of event'?

The gender (im)balance within this sample group reflects wider trends. MORI research from 1987, for example, found that 'twenty-five percent of women are prepared to describe themselves as "very interested" in the Royal 
Family, as compared with eleven percent of men'. ${ }^{8}$ The lone male respondent demonstrated the least interest in and engagement with royal events, claiming to have attended only at the behest of friends. Because of the small size of the sample group, it is problematic to suggest that they are representative of audiences for royal events, but they may constitute an indicative 'snapshot' of opinion and experience.

Popular interest in the monarchy is, Ben Pimlott suggests, largely media-generated, and 'Since the Monarchy and media are today so closely enmeshed ... it has become impossible to imagine modern royalty except in the context of a spotlight." As Michael Billig asserts, the British monarchy 'does not survive as an embarrassing relic, shuffling along like an elderly relative, conscious of being in the way of the younger generation. Quite the contrary, it survives by being noticed, over and over again. ${ }^{10}$ Buckingham Palace actively constructs royal media coverage and image-marketing, employing professional press secretaries and publicity agents, generating press releases and photo opportunities and, in the digital age, producing official websites. Despite some anxieties in the early years of broadcasting that too much publicity might 'stain the mystery, even the dignity of the Crown', ${ }^{11}$ the necessity of modern technology and media coverage in facilitating the royal family's function of 'perpetuating the national community through the provision of unifying symbols and rituals', ${ }^{12}$ came to be accepted, and eventually embraced, by both Crown and country. David Cannadine recounts that

the B.B.C.'s first director general, Sir John Reith, himself a romantic devotee of pageantry and the monarchy, rapidly recognised the power of the new medium to convey a sense of participation in ceremonial which had never been possible before. So, from the time of the Duke of York's wedding in 1923, 'audible pageants' became a permanent feature of the B.B.C.'s programmes, as each great state occasion was broadcast live on the radio, with special microphones positioned so that the listener could hear the sound of bells, horses, carriages and cheering. In a very real sense, it was this technical development which made possible the successful presentation of state pageants as national, family events, in which everyone could take part. ${ }^{13}$

The Queen's coronation in 1953 was the first major international event to be broadcast on television, with an estimated 20.4 million viewers in the UK alone, 56 per cent of the adult population. The coronation was the first media event seen by the majority of the population, and was for many their first experience of 'watching the box'. It is an event that has become a touchstone 
in the mythology of the nation and the memories of millions. This history supports the assertion by Dayan and Katz that successful media events have three partners:

the organizers of the event who bring its elements together and propose its historicity [in this instance, the Crown]; the broadcasters who re-produce the event by recombining its elements; and the audiences, on the spot and at home, who take the event to heart. Each partner must give active consent and make a substantial investment of time and other resources if an event is to be successfully mounted for television. Indeed, it is useful to think of such events as constituting a kind of 'contract' among the three parties whereby each side undertakes to give something to the others in order to get something in return. ${ }^{14}$

It has been argued that media ubiquity 'democratised' the British monarchy, citing, for example, the force of public opinion that led to the televising of the coronation, overcoming the resistance of Crown, church and government. While John Balmer's suggestion that this led to a shift in power, with the British public now controlling the destiny of the royal family, is undoubtedly overstating the case, we can none the less argue that in the media age, 'the function of royal events is to entertain and provide a spectacle for consumption'. ${ }^{15}$ Apparently paradoxically, the more modern and sophisticated broadcast technology has become, the more important it becomes that the 'ancient' and 'traditional' form a part of the ceremonial. As David Cannadine observes: 'If, for example, the queen had travelled to St Paul's Cathedral in a limousine [rather than the horse-drawn state coach] for her Jubilee Thanksgiving Service, much of the splendor of the occasion would have been lost. ${ }^{16}$ Balmer argues that we can perceive the British monarchy as a "corporate brand', the survival of which is dependent on 'accommodating political, economic, social, and technological change'. ${ }^{17}$ As a brand, the British royal family, Otnes and Maclaran suggest, offers 'tangible benefits. These include providing consumers with a respected and shared symbol of nationalism, helping them engage in national "togetherness" and fostering a sense of identity based on shared history, culture and traditions. ${ }^{18}$ We might categorise the royal media events and the 'live' experiences arranged round them examined here as part of the 'plethora of industries', that 'produce goods, services and experiences specifically designed to enhance consumers' knowledge and enjoyment of the $\mathrm{B}\left[\right.$ ritish] R[oyal] F[amily]. ${ }^{19}$ 
While to some extent the British monarchy can be thought of as global celebrities, Billig warns against making glib or misleading comparisons because

Royals are uniquely different from other show business celebrities. ... In the first place ... the stars of the entertainment industries ... are [not] held to embody a national heritage and the future of a nation. There is a second crucial factor which confirms the uniqueness of royal fame. In contemporary life, there are no other figures who are guaranteed a lifetime of celebrity from the moment of birth. Indeed the interest of the media guarantees fame from the moment of possible conception. This fame is transmitted across generations. The sons and daughters of today's film stars and sporting heroes will fade into anonymous obscurity, unless they manage to gain celebrity in their own right. But it is not so with the royals - they, their unborn children and grandchildren are known to be famous, whatever they do.

In a world of obsolescence, the transmission of royal celebrity across the generations has special significance. ${ }^{20}$

One of my interviewees, who joked that she enjoyed 'waiting outside in the cold', also regularly attended film premieres and other 'red carpet events', but stated that there was a distinct difference between these and royal occasions. Apropos the royal wedding, the event with perhaps the most evident 'movie star glamour', she said:

As much as there was a celebrity factor to it, I think it was first and foremost about patriotism and what it represented to the country, and being a historical event, and ... all of that was just much more important. I think just because it was William's wedding, and Kate became such a celebrity, there were a lot of different factors that played in. The celebrity, the Diana factor, and just everything that goes with the two of them that made it a little bit special in that sense, but I think in general that it's always going to be more about the country and the royal family and what it represents. ${ }^{21}$

This supports Blain and O'Connell's assertion that while it 'may be true that the phenomenon of monarchy in the media is primarily economic and secondarily political ... it seems to have acquired economic and political importance because it is originally of cultural and psychological importance'. ${ }^{22}$ Although popular veneration for royalty does fluctuate somewhat, only a very small proportion of the British population identify as republican, and MORI polls and the British Social Attitudes Surveys demonstrate that support for the monarchy is found among all social groups. ${ }^{23}$ 
Although, as we have seen, the notion that the mass media have the potential to create communities of interest and imagination is not a new one, the experience of watching live, mediated happenings in public and en masse is certainly novel. Until recently, the dominant conceptual framework for understanding large media events was that advanced by Daniel Dayan and Elihu Katz. They defined 'media events' as live television broadcasts, organised by establishment bodies, which 'stand for consensual values and have the authority to command our attention'. ${ }^{24}$ These can generate vast audiences, and although facilitated by technology, this is achieved by a 'norm of viewing', ${ }^{25}$ which portrays it as valuable, even mandatory to watch, and demands an element of active participation from the audience, such as watching in groups, dressing for the occasion and in doing so constructing their own celebrations around the event. Broadcasts of royal celebrations, such as coronations, jubilees and weddings, are paradigmatic of such a model. Dayan and Katz assert that media events privilege the home and observe that:

This is where the 'historic' version of the event is on view, the one that will be entered into collective memory. Normally the home represents a retreat from the space of public deliberation. ... Yet the home may become a public space on the occasion of media events, a place where friends and family meet to share in both the ceremony and the deliberation that follows. ${ }^{26}$

This account chimes with John Ellis's characterisation of the broadcast television viewer as 'a bystander in very specific circumstances, those of the home'. ${ }^{27}$ Live public screenings challenge this assumption, however, and raise questions about what happens to the nature of both broadcasts and their audiences as a consequence of this translation.

A mutual characteristic of both public and domestic consumption of media events is that they are usually shared with 'special' people, and are treated as occasions to reactivate family bonds, friendships and neighbourhoods. Representatively, all but one of my respondents, who had been unable to find her friends on the day, had attended the royal screenings with at least one friend or family member, and the shared nature of the experience was evidently an important aspect. In some cases the royal event seemed to be a pretext for a social occasion. One wrote, 'We thought it would be fun to make an event of it - friends came from Oxford and we had a picnic. ${ }^{.28}$ However, media events can also 'create their own constituencies" ${ }^{29}$, generate temporary communities and social networks who share an experience, a historical moment together. 
Another of my respondents said, for example: 'It felt like everybody had come together as a group of friends even though none of us knew each other. ${ }^{30}$ These alliances serve, argue Dayan and Katz, to reinforce the status quo: '[B]roadcasts integrate societies in a collective heartbeat and evoke a renewal of loyalty to the society and its legitimate authority. ${ }^{31}$

Thus, the event connects center and periphery, not only through the experience of communitas, but through direct communion with central symbols and values, through the assumption of ritual roles in a ceremony conducted by establishment leaders, and through the presence of small groups of known and valued others. $^{32}$

Again, although this is an analysis that can clearly be extended to sporting, military or cultural spectacles, these characteristics are most literally and profoundly expressed, I would argue, by broadcasts of royal ceremonial.

Media events have a complex relationship with the 'live' and the 'real'. Philip Auslander observes that the 'live' is a consequence of the mediated, rather than the reverse; prior to the development of recording technologies, there would have been no concept of the 'live' event, 'for that category has meaning only in relation to an opposing possibility'. ${ }^{33}$ Through its intervention, argue Dayan and Katz, television itself 'becomes the primary performer in the enactment of public ceremonies ${ }^{3}{ }^{34}$ Consequently it becomes meaningless to ask whether 'this type of broadcast offers a "true" rendition of the original event. Given the openly "performative" nature of television's role, the problematics of "truth" and "falsehood" become almost irrelevant here. ${ }^{35}$ Auslander argues that television has become the dominant form that the live event seeks to resemble, rather than vice versa, while Steve Wurtzler goes so far as to suggest that the live event has come to be seen as a 'degraded' version of the mediatised. ${ }^{36}$ However, Auslander asserts too that liveness and mediatization must be seen as a relation of dependence and imbrication rather than opposition ${ }^{37}$ and questions whether there remain 'clear-cut ontological distinctions between live forms and mediatized ones'. ${ }^{38}$ Dayan and Katz propose that we should regard the media event as sui generis: 'Neither reproduction nor access, it offers an experience in its own right, different from the original, and probably more important. ${ }^{39}$ Perhaps paradoxically though, media events continue to fetishise the 'real'; television claims to give its viewers a sense of 'being there'. Having generated the concept of the live, broadcast media 
must compensate for its lack, by offering intimacy, apparent proximity and equality of access.

Media events 'institutionalize a cinematographic model of "publicness" , ${ }^{40} \mathrm{a}$ characteristic emphasised by the emergence of public screenings.

With electronic communication, the reconstituted performance can be simultaneous, within a temporal frame shared by all protagonists and by the audience. These are 'live' broadcasts, which means that simulation of a performance has reached a state of near-perfection: it has become temporally indistinguishable from the performance itself. This live dimension of the broadcast ostensibly returns us to theater and church. But shared time conceals another dimension of the cinematographic model: that public reaction is no longer a reaction to the original performance, but to its simultaneous substitute. ${ }^{41}$

In June 2009, the National Theatre in London initiated a popular phenomenon when it broadcast by satellite a live theatrical production to 70 cinemas in the UK and a further 210 around the world. An estimated 50,000 people saw the play as it was performed. These audiences may have been geographically distant from that in the theatre, but they none the less witnessed the show at the same time, and were spatially co-present to the others in the cinema where they watched. Bakhshi and Throsby's research suggests that the expectations and experiences of the audiences in the theatre and the cinemas had more in common than not, and the 'experiential aspects', the sense of occasion and 'the buzz' of the performance were valued by both. In both cases, the chance to see the actors 'up close' was reported as an important factor, and significantly, nearly 85 per cent of the cinema audiences 'reported feeling "real excitement" because they knew the performance they were watching was taking place "live" at the National Theatre'. As Bakhshi suggests: '[ $t$ ]his finding suggested that there are limits to the "anywhere, anytime" attitude towards the consumption of cultural content. It would seem that there does exist a "right time" (live, as it happens) and a "right place" (a cultural venue, whether a theatre or a cinema) to enjoy some cultural experiences. ${ }^{32}$

This could be seen as an exemplar of what John Urry conceptualises as a particular 'kind of travel to place, where timing is everything'.

This occurs where what is experienced is a 'live' event programmed to happen at a very specific moment. Co-presence involves 'facing-the-moment'. Examples include political, artistic, celebratory, academic and sporting occasions. ... Each of these generates intense moments of co-presence. These 
events cannot be 'missed' and they set up enormous demands for mobility at very specific moments. ${ }^{43}$

Clearly my respondents who attended public broadcasts of royal events were responding to these demands, and appear to substantiate Mike Weed's assertion that the 'need for proximity is not for proximity to the event, but to others sharing in the experience of watching the event'. ${ }^{44}$ Deirdre Boden and Harvey L. Molotch likewise identify a 'compulsion of proximity', ${ }^{45}$ and observe that 'When we are in copresence, we have some evidence that the other party has indeed made a commitment, if nothing else than by being there. ${ }^{46}$ This sense of 'fellow feeling' was greatly valued by the majority of my respondents; one said that they 'wanted to be around people to experience the sense of community and shared excitement'. ${ }^{47}$ Thus it would seem that if, as Dayan and Katz assert, media events initially 'shifted the locus of ceremoniality from the piazza and the stadium to the living room', ${ }^{48}$ then live screenings have shifted it right back. This contradicts many earlier assumptions about the perceived benefits and likely consequences of domestic media. Television was touted as a way of avoiding the stress and discomfort of travel and mass outdoor events, of crowds and the risk of 'social contamination', but it appears that these are 'risks' that many are willing to take. A significant constituency evidently welcomes opportunities for communality and engagement and, in this context, as Haferburg, Golka and Selter observe, big screens can have 'an important impact on public space and life' ${ }^{49}$ Simone Arcagni concurs, proposing that the media event 'reinstates the function of public space as a place of public use, and above all, defines the spectator who wants to see but also participate'. ${ }^{0}$

Watching live screenings in public places could be argued to be, and in many cases seemed to be experienced as, a sort of 'win-win' situation. David Rowe, writing about sporting contexts, observes that while the viewer of an event on television must forgo the atmosphere and excitement of the live experience, they are compensated with ' [e]xpert commentary, multi-camera angles (from panoramas to extreme close-ups), split screens, "wired" officials, directional microphones, action replays, super-slow motion, and so on'. ${ }^{51}$ Audiences who are present at live events get to enjoy the atmosphere and excitement from being part of a like-minded crowd, and the sense that they are part of history in the making, but may find that as a result of a variety of restrictions, they actually get to see little or nothing of the event itself, often a partial view of a fleeting moment at best. But as Rowe observes, the 'insertion of televisual infrastructure into the event itself' can overcome these problems 'for an "in-person audience ... unsure about whether it should not be 
at home, watching TV" for fear of only "attending part of the event", when with television "everybody can attend the whole event" ". ${ }^{52}$ This has the effect of reversing the 'spectatorial dynamic', because 'instead of transmitting images of unique spatio-temporal events to remote locations, the attending spectator is provided with multiple versions of what they have seen (or have not or could not) as if they were absent ${ }^{53}$ Other commentators, however, are more sceptical about the advantages or pleasures of such a set-up. Auslander argues that 'The spectator sitting in the back rows of a Rolling Stones or Bruce Springsteen concert ... is present at a live performance, but hardly participates in it as such since his/her main experience of the performance is to read it off a video monitor. ${ }^{54}$ Goodwin goes so far as to suggest that 'attending a live performance ... these days is often roughly the experience of watching a small, noisy TV set in a large, crowded field'. ${ }^{5}$ Even if this were true, 'the enforced scarcity of the in-person experience, as opposed to the automatic plenitude of its living room equivalent, seems to still tip the balance in favour of "being there", ${ }^{56}$ suggests David Rowe. Several respondents said they were motivated by the opportunity to experience a 'once-in-a-lifetime event', to 'feel the atmosphere and be able to say, "I was there!" '.57 As one said, 'I think there are very few circumstances in which you can be part of something that you know for sure will be part of History, and I guess many people went for that reason. ${ }^{58}$ Related to this is the desire, perhaps unconscious, to accrue cultural and social capital. Auslander suggests that a 'dimension to the question of why people continue to attend live events in our mediatized culture is that live events have cultural value: being able to say that you were physically present at a particular event constitutes valuable symbolic capital. ${ }^{59}$ One of my respondents spoke about the 'human need for this authentic experience, ${ }^{60}$ although she acknowledged that such experiences could be amplified in the recalling and the retelling, 'so even if they see the top of one flag, which is literally all I saw, that's going to be "Oh, we watched the Jubilee flotilla"' ${ }^{61}$ Another, who had arrived early at the riverside to guarantee a view of the live action, stressed why this was important: 'I think the idea of seeing it in person makes it something memorable. You have to actively seek out the event to participate - wake up early, stake a spot out, sit in the rain, etc. - that it becomes something that you have done rather than something others have merely watched. ${ }^{62}$ But none the less we see similar claims made for both mediated and immediate experiences, which reflects Auslander's questioning of whether there remain 'clear-cut ontological distinctions ${ }^{36}$ between them.

It is important for media events to attract a live crowd, so that something of the atmosphere and significance of the event can be conveyed to the audience 
watching at home. As Rowe observes: '[I]t is unlikely that global media events founded, however imperfectly, on the premise of recording history, can readily dispense with the audible and visible witness of a large attending crowd. ${ }^{64}$ In the context of royalty, streets thronged with flag-waving subjects give the continued presence of the monarchy in public life a sense of legitimacy, and audiences attending live screenings of events may find themselves simultaneously spectator and spectacle. Rowe notes that

the use of televised 'reaction shots' of screen spectators in public (or quasi public) spaces outside the event is a device that extends the spectacle of the crowd beyond the ... [event proper].... Television in this way seeks to compensate those who did not or could not attend by giving them a 'bit part' in the festival, while implicitly reinforcing for the wider viewership the aura of the event and the ultimate desirability of seeing it three-dimensionally and of 'feeling it' through all available senses. ${ }^{65}$

In sporting contexts this is illustrated by the coverage of 'Murray Mound' at Wimbledon, and 'Park Live' at the London Olympics, and is increasingly the case at royal events also. Rowe makes the further observation, supported by my findings, that audiences at screenings behave much as those at live events might be expected to. He writes that: 'The experiential synthesis occurring at public "screenings" was evident in forms of crowd interaction - chanting before the screen and applauding the two-dimensional images of athletes. ${ }^{66}$ One of my respondents recalled seeing a group of Jamaican spectators watching Usain Bolt during the Olympics on public screens in London: 'people were glued to the screen and looked beside themselves with excitement' ${ }^{67}$ Intensity of experience, then, can be a consequence as much of the emotional engagement of spectators as of their location, a characteristic common to both royal and sporting occasions, it would seem.

The emotional engagement created by communal viewing was recalled by a respondent who had attended the screening of the Diamond Jubilee concert:

You have a thousand other people with you who are dancing and singing and screaming, and it just becomes like a festival, community experience, which you wouldn't have otherwise. I know in the past we've had, I don't know, Eurovision Song Contest parties and things like that, where you all watch it on a TV ... but seeing it in a public space like Hyde Park just takes it to a whole new level. ${ }^{68}$

Another said that the atmosphere in the crowd 'was incredible. I don't think I've ever experienced being among so many people where everyone was so visibly 
happy and excited. ${ }^{69}$ She recalled that she and her friends had considered going to a pub to watch the concert, because they thought

\begin{abstract}
it would have been pretty much the same thing, and probably more comfortable because we wouldn't have to go through the crowds to get to a park and just sit on the ground, but by that point we had been to all the other events and we were just so excited to be around everyone, and we realised what a fun experience it was, and it was really just the sense of community that was happening while we were there. ${ }^{70}$
\end{abstract}

This supports Mike Weed's observation that with the advent of live screenings the key question becomes

not 'being there' but 'being where?' - that is, what places or venues are going to provide the best communal ... experience? Because the 'there' in 'being there' has become so fluid, as has the range of experiences available, the question that fans may now ask each other is less likely to be 'were you there?' but rather 'where did you watch?' and 'what was it like?"71

One respondent said that being part of a crowd made the live screening seem 'more realistic, it feels more like you're actually at the event if there's other people screaming and cheering and wearing British flags and that kind of thing ${ }^{72}$ Another, who had watched the royal wedding on screens in Hyde Park, claimed that she and her friends had actually felt 'closer to the action watching it as part of a crowd than squashed by the side of the road watching a glimpse of it. I have never regretted not going to try and see them in the flesh'. ${ }^{73} \mathrm{~A}$ third recalled the (perhaps surprising) intimacy that the event generated:

There was actually a moment when Kate was walking down the aisle ... up to Prince William, and when the actual ceremony took place and they exchanged the rings, and there was a really kind of 'goosebump' moment, because all of Hyde Park just went silent for quite a while, which was really emotional. I remember the girl next to me, who was British, started crying as well, which was really peculiar to see because we were in this huge space, with this whole bunch of people, and you have these screens up and people really are feeling raw emotions, and that was special, I guess. You felt like you were part of it in Westminster Abbey, you were kind of there with them in a way. ${ }^{74}$

These reports would seem to reflect Nairn's observation that '[c]rowd emotion is notoriously communicable, and hard to resist; people speak of being "carried away". The point of this sort of popular coming-together ("crowd" 
hardly seems to fit) is that the participants are sustained by the feeling of doing something. ${ }^{35}$

Interestingly, this sense of the crowd as a unified collectivity was felt just as acutely by the one respondent who had been a reluctant attendee; he, however, experienced it more as an oppressive uniformity. He reported that at both the royal concert and the Olympics screening he had attended, for him, the 'fervent nationalist tone undermined the positive aspects of the occasion', because 'when flags are involved I feel it becomes less about inclusion, more about cultural territorialism'. ${ }^{76} \mathrm{He}$ recalled that his

intention for going ... [to the Jubilee concert] was more to do with the music than anything else, but when we got there it was clear that the crowd was more of a royalist fan than a pop music fan. I think it was that crowd element that made me ... that upped the discomfort level. ... It's kind of the general atmosphere of feeling that you're then a part of that is very ... I found it a mixture of distaste and alienation, because you are in that environment, and you're not just watching it, you're actually physically a part of it. So there's a certain really affective element there ... the alienating aspect was very tangible and almost physiological. You could feel your muscles tense and breath shorten a bit. I don't want to over-egg it ... but you're bounded by conventions, and in St James's Park you are surrounded by very lovely people, lots of families, young children, older people, all having a lovely time, at least that's the sense you get, and you don't want to start ... not that I would anyway, outwardly dissenting and protesting. ... And also with my friends who were a lot more ... I got the impression from them they were a lot more able to just enjoy themselves, I think. ${ }^{77}$

The difficulty of dissenting in such circumstances, even for those with the stomach for it, was indicated by another respondent, an enthusiastic royalist, who recalled seeing a group of about twenty republicans at the Jubilee pageant; she reported that they turned up

with some posters and everything, and every time they started chanting, the whole crowd just started chanting 'God Save the Queen' together, to completely drown out their sound. After a while they just gave up, because there was no point in even trying. They wouldn't be able to show their posters, they wouldn't be able to get anything across. ${ }^{78}$

However, respondents also reported less intense modes of engagement, resembling the mode identified by Haferburg et al. in their research on screenings during the 2010 football World Cup. They propose that big screen 
transmissions have a capacity to create a more 'laid-back' form of spectatorship, a consequence of the distance that the screens impose between the audience and the action. They suggest that this 'detached' type of viewing could be 'more like a pub experience or even a picnic with some entertainment in the background'. ${ }^{79}$ Reflecting this, one of my respondents reported that the atmosphere amongst the crowd watching the Jubilee concert was 'excited, relaxed, easy-going, like being at a festival'.$^{80}$ Another recalled: 'So ... we had our picnic with us, we had our blankets with us, it was a warm sunny day and I was there with a set of friends. ... Half of it was going to see the concert, half of it was "let's have a nice day in Hyde Park because it's sunny outside" kind of thing. ${ }^{81}$

Of all the events discussed, my respondents reported the greatest satisfaction with the Jubilee concert. One reason appeared to be that this was a spectacle that could, by the general public at least, only be watched on screens. Because there was no hope of seeing the action live, expectations were fulfilled. All spoke of a party atmosphere, and good views and sound from screens and speakers. One recalled that

as soon as the concert kicked off, everyone stood up and it was literally like a festival. People were dancing, and you kind of forgot, because again the concert was taking place at Buckingham Palace and it was so close to Hyde Park, I think all of Hyde Park pretended that we were watching the concert live instead of on the screens, because that's how people engaged with it. ... People forget that you're not actually watching it live, well you are watching it live, but you're not at the event. ${ }^{82}$

The majority of respondents stated that the proximity of the screens to the live action was none the less an important contributor to the atmosphere, their enjoyment and the sense of uniqueness of the event. One recollected that

it felt ... like the screen was almost like a tunnel through the trees, because there were loads of trees around the Palace and St James's Park, that get in the way, so maybe it felt like it was just a little portal, I suppose, whereas if it had been in some other distant location maybe it would have been a bit more ... it could have been just a recording. ${ }^{83}$

Several remarked on the excitement of seeing the post-concert fireworks on both the screen and in the sky above them, and that this made it 'that much more special to have that proximity' ${ }^{84}$ Similarly, a respondent who watched the royal wedding on screens in Hyde Park enjoyed the fact that during the RAF 
flyover 'as soon as the planes flew over the balcony [at Buckingham Palace, on which the newlyweds were standing] and they lifted their heads, that moment, then the planes ... flew over us, which ... made it special too because you felt the proximity to the whole event' ${ }^{35}$ Proximity can also afford other unexpected advantages. An American visitor to London during the Queen's Golden Jubilee in 2002 witnessed a public appearance by the Queen and Prince Philip after watching the screening of the 'Prom at the Palace' classical concert in the Mall. He recalled that he 'saw them in the flesh for the first time which was thrilling, although the crowd was so thick that it was hard to get a good view' ${ }^{86}$

These recollections illustrate Billig's observation that: 'Present royal moments, whether those of the great televised occasions or the moment when an ordinary person receives the touch of a royal hand-shake, are construed as being inherently memorable. ${ }^{87}$ The last quotation, however, does perhaps point to the limitations of mediated experiences, and what Ziegler calls 'the almost magical significance ${ }^{88}$ attached by many to seeing royalty in person. One respondent reflected that:

What I really got from these events was that I can't imagine the Royal family ever not existing, because there was such an outpouring of love and support and loyalty, that it's really difficult to explain to people who have never experienced this and haven't grown up with this, to understand what happens to people when the Queen passes by, and how people completely lose themselves, and they're so happy, and can't wait to show their support. ${ }^{89}$

Consequently, although casual royal watchers' priorities may be comfort and sociability, more engaged fans will aim for an experience as close to the intensity of the 'live' show as possible. One respondent had camped out on the street for a glimpse of royalty in the flesh at both the royal wedding and the Jubilee Thanksgiving Service.

Whether a sense of 'presentness' was achieved varied amongst respondents and between events. While satisfaction was reported in instances where the screen was the only available mode of spectatorship, responses were more ambivalent about the Jubilee river pageant, where it was theoretically possible to watch both screened and live action. Some enjoyed the dual experience, being able to both compensate for a restricted view and to feel that they were getting a more 'rounded' view of the event. One said, ' $[I]$ t was really nice, because we were watching the small boats coming through ... and then every once in a while you'd have the Duchess of Cambridge popping up on the big screens. ${ }^{90}$ 
While several respondents reported that there seemed to be little difference in the responses of the crowd to live or screened action, with the nature of the action and personnel on view apparently the primary determinant of levels of noise and enthusiasm, others complained that engagement was impeded by the poor placing of some screens and technical difficulties with defective sound and vision. As Barker suggests, 'the whole point for audiences of livecasting appears to be its capacity to be invisible as technology. Enthusiastic audiences for a livecast don't want to be reminded of the fact that it is being transmitted ... blips in transmission ... disrupt concentrated participation. ${ }^{.91}$ Some identified a problem of 'disconnect' between the screened content (the BBC's programming consisting of a mixture of event footage and related features) and what could sometimes be glimpsed in front of them. One said that:

If it had been there as sort of a guide, so you knew when she [the Queen] was passing by, that might have been a bit more useful. ... So, if we had seen the screen and gone 'okay, so she's just passed the Albert Bridge, we know where she is' ... because there was a point when everyone started cheering and we're like, 'Okay, was that her?', because we didn't know. ${ }^{92}$

Although this respondent also acknowledged that it was actually just neat to be there with all the other people decked out in Jubilee gear and very excited about the event' ${ }^{33}$ most who had only been able to see the screens expressed disappointment, and regarded their experience as second best. It seemed to be the very immediate proximity of the screens to the action that prompted this disenchantment. One mused:

When you're faced between the option of 'Oh, there's a screen right here, I can watch it on the screen' or it's actually going on right behind me, it didn't really work and it's sort of hedging your bets as to whether you're actually going to see anything on the river as opposed to just stopping and watching the screen. Watching the screen kind of felt like cheating out on it, in that sense, it's sort of like 'Oh! I'm just going to go for this', when really you're right there anyway, so you might as well just try to see it. ${ }^{94}$

Certainly the respondents who had attended the Jubilee river pageant screenings in parks rather than by the Thames appeared to have enjoyed themselves more, but factors such as bad weather and other forms of physical discomfort perhaps need to be taken into account here, too.

One interesting finding of the research was that a high proportion of respondents, whether or not they had enjoyed a satisfactory experience and a good view 
of the action at the events themselves, stated that they watched the event on television or online when they got home. It seems that domestic television is still regarded as the optimum medium for conveying information, if not atmosphere. This respondent offered a representative recollection:

I remember going home and then watching the whole thing again on television as well, because ... when you are in the park there is so much emotion to it, and you were distracted by other people as well and their reactions were kind of beautiful, but you did kind of want to have that moment when you watched the highlights on TV to make sure you saw every single minute of it because it was really nice. ${ }^{95}$

For this and other reasons, it is important, as Scott McQuire asserts, to 'demarcate these public rituals [generated by the introduction of live coverage on big screens] from the older social function of television'. ${ }^{96}$ In the context of a fragmenting and globalising media landscape, and a more diverse and geographically mobile audience, the increasing ubiquity and popularity of large screens as a focal point for public gatherings in public space may be taken to represent a desire for new forms of collectivity. These occasions differ from their more traditional counterparts because 'the screen does not so much substitute for a public gathering as become the occasion for one' ${ }^{97}$ My research suggests that in attending these public screenings, people seek not only communality but also, and apparently paradoxically, the 'live' experience, a sense of 'being there' and the chance to claim themselves witnesses to history.

Although beyond the scope of this paper, there is evident potential for future research to examine not just the impact of big screens, but how these combine with other types of new media, in particular the Internet and mobile devices. As McQuire observes, the 'cumulative impact of these developments on the relation between media and public space has been profound' ${ }^{98}$ We live in an era of "media platforms which move so fast that they no longer merely "represent" events, but become part of them, foreshadowing the role of near instantaneous feedback loops in shaping contemporary experience of public space'. ${ }^{99}$ Examples of this include live tweeting from public events, and videos, hosted on YouTube, which capture the responses of the crowds watching the televised relay of the 2011 royal wedding on the big screen in Trafalgar Square. ${ }^{100}$ As an explanatory framework Barker offers 'the idea of "intermediality" ... a world of increasingly interpenetrative media which constantly cross-refer'. ${ }^{101}$ 
As we have seen, the British monarchy themselves are active participants in this brave new media world. Conscious that their survival depends to a large part on popular support, they have embraced social media and the digital, and boast Facebook, Flickr and Twitter accounts. Although, as Billig suggests, the 'appearance of antiquity might be appealing to something genuinely old within the psyche of monarchy's subjects', it is perhaps more likely that 'present times are producing states of mind which are drawn to the appearances of tradition. Monarchy, thus, fits today's modern, perhaps post-modern, times. ${ }^{\prime 02}$ Royalty meets contemporary needs through representing an apparently timeless heritage via the newest forms of media. While an encounter with royalty 'in the flesh' has lost none of its thrill, this compulsion for proximity will continue to be generated primarily through the reproduction of their image on an ever-growing diversity of screens.

\section{NOTES}

1 Scott McQuire, 'Rethinking media events: large screens, public space broadcasting and beyond', New Media and Society 12:4 (2010), p. 569.

2 Michael Barker, Live to Your Local Cinema: The Remarkable Rise of Livecasting (Basingstoke: Palgrave Macmillan, 2013), p. 10.

3 Ibid., p. 57.

4 Michael Billig, Talking of the Royal Family (London: Routledge, 1992), p. 12.

5 Tom Nairn, The Enchanted Glass: Britain and Its Monarchy (London: Verso, 2011), p. 11.

6 Ibid., p. 106.

7 Respondent 1.

8 Cited in Billig, Talking of the Royal Family, p. 173.

9 Ben Pimlott, 'Monarchy and the message', Political Quarterly 69:B (1998), p. 106.

10 Billig, Talking of the Royal Family, p. 1.

11 Philip Ziegler, Crown and People (London: Collins, 1978), p. 155.

12 Clifford Stevenson and Jackie Abell, 'Enacting national concerns: Anglo-British accounts of the 2002 royal Golden Jubilee', Journal of Community \& Applied Social Psychology 21 (2011), p. 126.

13 David Cannadine, 'The context, performance and meaning of ritual: the British monarchy and the "invention of tradition", c. 1820-1977', in Eric Hobsbawm and Terence Ranger (eds), The Invention of Tradition (Cambridge: Cambridge University Press, 2013), p. 142.

14 Daniel Dayan and Elihu Katz, Media Events: The Live Broadcasting of History (London: Harvard University Press, 1994), p. 54.

15 Stevenson and Abell, 'Enacting national concerns', p. 126.

16 Cannadine, 'The context, performance and meaning of ritual', p. 156. 
17 John M. T. Balmer, 'A resource-based view of the British monarchy as a corporate brand', International Studies of Management \& Organization 37:4 (2007-8), p. 36.

18 Cele C. Otnes and Pauline Maclaran, 'The consumption of cultural heritage among a British royal family brand tribe', in Bernard Cova, Robert V. Kozinets and Avi Shankar (eds), Consumer Tribes (Oxford: Butterworth-Heinemann/Elsevier, 2007), p. 52.

19 Ibid., 52.

20 Billig, Talking of the Royal Family, pp. 220-1.

21 Respondent 5 in interview.

22 Neil Blain and Hugh O’Donnell, Media, Monarchy and Power (Bristol: Intellect, 2003), p. 60.

23 The most recent British Social Attitudes Survey finds that while the UK is still a long way from levels of royal support in the 1980s, when 65 per cent said it was 'very important' for Britain to continue to have a monarchy, there has none the less been a turnaround in opinion - from 27 per cent expressing strong support for the royal family in 2006 to 45 per cent in 2013. See www.bsa-30.natcen.ac.uk/ read-the-report / key-findings / trust,-politics-and-institutions.aspx.

24 Dayan and Katz, Media Events, p. 6.

25 Ibid., p. 8.

26 Ibid., p. 22.

27 John Ellis, Visible Fictions: Cinema, Television, Video (London: Routledge, 2000), p. 160.

28 Respondent 2.

29 Dayan and Katz, Media Events, p. 15.

30 Respondent 3.

31 Dayan and Katz, Media Events, p. 9.

32 Ibid., p. 196.

33 Philip Auslander, Liveness: Performance in a Mediatized Culture (London: Routledge, 1999), p. 51.

34 Dayan and Katz, Media Events, p. 78.

35 Ibid.

36 Steve Wurtzler, 'She sang live, but the microphone was turned off: the live, the recorded, and the subject of representation', in Rick Altman (ed.), Sound Theory, Sound Practice (London: Routledge, 1992), p. 92.

37 Auslander, Liveness, p. 53.

38 Ibid., p. 7.

39 Dayan and Katz, Media Events, p. 79.

40 Ibid., p. 210.

41 Ibid.

42 Hasan Bakhshi, 'Measuring cultural value', Keynote speech delivered at 'Culture Count: Measuring Cultural Value' forum, Customs House, Sydney, Australia, 20 March 2012, www.nesta.org.uk/areas_of_work/creative_economy/assets/ features/measuring_cultural_value, p. 5 .

43 John Urry, 'Mobility and proximity', Sociology 36:2 (2002), p. 262. 
44 Mike Weed, 'The pub as a virtual football fandom venue: an alternative to "being there"?', Soccer \& Society 8:2-3 (2007), p. 411.

45 Deidre Boden and Harvey L. Molotch, 'The compulsion of proximity', in Roger Friedland and Deidre Boden (eds), NowHere: Space, Time and Modernity (London: University of California Press, 1994), p. 258.

46 Ibid., p. 263.

47 Respondent 3.

48 Dayan and Katz, Media Events, p. 211.

49 Christoph Haferburg, Theresa Golka and Marle Selter, 'Public viewing areas: urban interventions in the context of mega-events', in Udesh Pillay, Richard Tomlinson and Orli Bass (eds), Development and Dreams: The Urban Legacy of the 2010 Football World Cup (Cape Town: HSRC Press, 2009), p. 175.

50 Simone Arcagni, 'Media architectures and urban screens as new media: forms, places and spectatorship', in P. Zennaro (ed.), Colour and Light in Architecture. Proceedings of the First International Conference on Colour and Light in Architecture (Verona: Knemesi Editori, 2010), http:/ / rice.iuav.it/211/1/05_arcagni.pdf., pp. 253-4.

51 David Rowe, 'Global media events and the positioning of presence', Media International Australia 97 (2000), p. 16.

52 Ibid.

53 Ibid.

54 Auslander, Liveness, p. 24.

55 Andrew Goodwin, 'Sample and hold. Pop music in the digital age of reproducing', first published in Critical Quarterly 30:3 (1988), repr. in Simon Frith and Andrew Goodwin (eds), On Record. Rock, Pop, and the Written Word (London: Routledge, 1990), quoted Auslander, Liveness, p. 26.

56 Rowe, 'Global media events', pp. 18-19.

57 Respondent 4.

58 Respondent 5 from questionnaire.

59 Auslander, Liveness, p. 57.

60 Respondent 6 in interview.

61 Ibid.

62 Respondent 7.

63 Auslander, Liveness, p. 7.

64 Rowe, 'Global media events', p. 16.

65 Ibid.

66 Ibid., p. 17.

67 Respondent 6 from questionnaire.

68 Respondent 8 from questionnaire.

69 Respondent 5 from questionnaire.

70 Respondent 5 in interview.

71 Mike Weed, 'Sport fans and travel: is "being there" always important?', Journal of Sport \& Tourism 15:2 (2010), p. 106.

72 Respondent 6 in interview. 
73 Respondent 2 from questionnaire.

74 Respondent 8 in interview.

75 Nairn, The Enchanted Glass, p. 79.

76 Respondent 9 from questionnaire.

77 Respondent 9 in interview.

78 Respondent 5 in interview.

79 Haferburg et al., 'Public viewing areas', p. 175.

80 Respondent 8 in interview.

81 Ibid.

82 Ibid.

83 Ibid.

84 Ibid.

85 Ibid.

86 Theodore Harvey, 'The Queen's Golden Jubilee weekend: a personal account', www.royaltymonarchy.com/opinion/jubilee.html.

87 Billig, Talking of the Royal Family, p. 221.

88 Ziegler, Crown and People, p. 107.

89 Respondent 5 in interview.

90 Ibid.

91 Barker, Live to Your Local Cinema, p. 54.

92 Respondent 6 in interview.

93 Respondent 6 from questionnaire.

94 Respondent 6 in interview.

95 Respondent 8 in interview.

96 McQuire, 'Rethinking media events', p. 574.

97 Ibid.

98 Ibid., p. 571.

99 Ibid.

100 See, for example, www.youtube.com/watch?v=iLXg8lhi8LM. Interestingly, in the context of this discussion, this video is titled 'Royal Wedding 29 Apr 2011, Live at Trafalgar Square, London, UK'.

101 Barker, Live to Your Local Cinema, p. 43.

102 Billig, Talking of the Royal Family, p. 56.

\section{BIBLIOGRAPHY}

Altman, Rick (ed.), Sound Theory, Sound Practice (London: Routledge, 1992).

Arcagni, Simone, 'Media architectures and urban screens as new media: forms, places and spectatorship', in P. Zennaro (ed.), Colour and Light in Architecture. Proceedings of the First International Conference on Colour and Light in Architecture (Verona: Knemesi Editori, 2010), http:/ / rice.iuav.it/211/1/05_ arcagni.pdf. 
Auslander, Philip, Liveness: Performance in a Mediatized Culture (London: Routledge, 1999).

Bakhshi, Hasan, 'Measuring cultural value', Keynote speech delivered at 'Culture Count: Measuring Cultural Value’ forum, Customs House, Sydney, Australia, 20 March 2012, www.nesta.org.uk/areas_of_work/creative_economy/ assets/features/measuring_cultural_value.

Balmer, John M. T., 'A resource-based view of the British monarchy as a corporate brand', International Studies of Management \& Organization 37:4 (2007-8).

'Scrutinising the British monarchy: the corporate brand that was shaken, stirred and survived', Management Decision 47:4 (2009).

Barker, Michael, Live to Your Local Cinema: The Remarkable Rise of Livecasting (Basingstoke: Palgrave Macmillan, 2013).

Billig, Michael, Talking of the Royal Family (London: Routledge, 1992).

Blain, Neil and Hugh O’Donnell, Media, Monarchy and Power (Bristol: Intellect, 2003).

Boden, Deidre and Harvey L. Molotch, 'The compulsion of proximity', in Roger Friedland and Deidre Boden (eds), NowHere: Space, Time and Modernity (London: University of California Press, 1994).

Cannadine, David, 'The context, performance and meaning of ritual: the British monarchy and the "invention of tradition", c. 1820-1977', in Eric Hobsbawm and Terence Ranger (eds), The Invention of Tradition (Cambridge: Cambridge University Press, 2013).

Cova, Bernard, Robert V. Kozinets and Avi Shankar (eds), Consumer Tribes (Oxford: Butterworth-Heinemann/Elsevier, 2007).

Dayan, Daniel and Elihu Katz, Media Events: The Live Broadcasting of History (London: Harvard University Press, 1994).

Ellis, John, Visible Fictions: Cinema, Television, Video (London: Routledge, 2000).

Friedland, Roger and Deidre Boden (eds), NowHere: Space, Time and Modernity (London: University of California Press, 1994).

Goodwin, Andrew, 'Sample and hold. Pop music in the digital age of reproducing’, Critical Quarterly 30:3 (1988).

Haferburg, Christoph, Theresa Golka and Marle Selter, 'Public viewing areas: urban interventions in the context of mega-events', in Udesh Pillay, Richard Tomlinson and Orli Bass (eds), Development and Dreams: The Urban Legacy of the 2010 Football World Cup (Cape Town: HSRC Press, 2009).

Harvey, Theodore, 'The Queen's Golden Jubilee weekend: a personal account', www.royaltymonarchy.com/opinion/jubilee.html.

Hobsbawm, Eric and Terence Ranger (eds), The Invention of Tradition (Cambridge: Cambridge University Press, 2013).

McQuire, Scott, 'Rethinking media events: large screens, public space broadcasting and beyond', New Media and Society 12:4 (2010).

Nairn, Tom, The Enchanted Glass: Britain and Its Monarchy (London: Verso, 2011). 
Otnes, Cele C. and Pauline Maclaran, 'The consumption of cultural heritage among a British royal family brand tribe', in Bernard Cova, Robert V. Kozinets and Avi Shankar (eds), Consumer Tribes (Oxford: Butterworth-Heinemann/ Elsevier, 2007).

Pillay, Udesh, Richard Tomlinson and Orli Bass (eds), Development and Dreams: The Urban Legacy of the 2010 Football World Cup (Cape Town: HSRC Press, 2009).

Pimlott, Ben, 'Monarchy and the message', Political Quarterly 69:B (1998).

Rowe, David, 'Global media events and the positioning of presence', Media International Australia 97 (2000).

Stevenson, Clifford and Jackie Abell, 'Enacting national concerns: Anglo-British accounts of the 2002 royal Golden Jubilee', Journal of Community \& Applied Social Psychology 21 (2011).

Urry, John, 'Mobility and proximity', Sociology 36:2 (2002).

Weed, Mike, 'The pub as a virtual football fandom venue: an alternative to "being there"?', Soccer \& Society 8:2-3 (2007).

Weed, Mike, 'Sport fans and travel: is "being there” always important?', Journal of Sport \& Tourism 15:2 (2010).

Wurtzler, Steve, 'She sang live, but the microphone was turned off: the live, the recorded, and the subject of representation', in Rick Altman (ed.), Sound Theory, Sound Practice (London: Routledge, 1992).

Ziegler, Philip, Crown and People (London: Collins, 1978). 
Ruth Adams - 9781526113047

Downloaded from manchesterhive.com at 04/26/2023 01:46:25PM via free access 